\title{
Health status and productivity of sheep fed coffee pulp during fattening
}

\author{
Jorge Hernández-Bautista a , Héctor M. Rodríguez-Magadána , José A. Villegas-Sánchez ${ }^{a}$, \\ Teodulo Salinas-Rios ${ }^{\mathrm{a}^{*} \text {, Iris Y. Ortiz-Muñoz }}{ }^{\mathrm{a}}$, Magaly Aquino-Cleto ${ }^{\mathrm{a}}$, Salvador Lozano-Trejo ${ }^{\mathrm{b}}$
}

\begin{abstract}
The objective of this study was to evaluate the productivity and health of fattening lambs fed different levels of coffee pulp in their diets. Thirty-five crossbred lambs with an average weight of $21.8 \mathrm{~kg}$ were fed isoproteic and isoenergetic diets with different percentages of coffee pulp (T0: control; T1: 7\%; T2: 14\%, T3: $21 \%$ and T4: 28\%), the base diet was formulated with corn, soybean meal, alfalfa stubble, molasses, urea and mineral salt. The fattening period was 98 days. Productivity was measured by weight gain, feed intake and feed conversion. At the beginning and end of the study, blood samples were taken to determine the health status using a biochemical profile and blood count. Analysis of variance was performed using the initial weight as the covariate for the productive variables and the initial values of the analytes in the blood chemistry and hematological analysis tests. The coffee pulp did not affect productivity, although the amount of neutrophils decreased $(P<0.05)$ as the coffee pulp in the diet increased. In all treatments, urea exceeded the reference values, whereas creatinine was below the reference values. We concluded that the inclusion of up to $28 \%$ coffee pulp in the diet did not affect the productive parameters, decreases the neutrophil count without affect health status of lambs during fattening.

Key words: coffee, creatinine, neutrophils, ovines, urea.
\end{abstract}

\section{INTRODUCTION}

Coffee pulp is the most abundant by-product obtained in the wet process of cherry, which contains high amount of fiber and $9.8 \%$ of crude protein (Salinas et al 2014). Coffee pulp has been included in ruminant feed to take advantage of this by-product and reduce feed costs. Up to $16 \%$ coffee pulp can be included when fattening sheep (Salinas-Rios et al 2015). In bulls, an intake of $1.65 \mathrm{~kg}$ of dry matter/animal/day of coffee husk does not affect weight gain; however, increasing the intake to $2.08 \mathrm{~kg}$ of dry matter/animal/day reduces daily weight gain (Barcelos et al 1997). Additionally, the digestibility decreases linearly with the inclusion of coffee husks (Souza et al 2006). In sheep, adding $112.5 \mathrm{~g}$ of coffee pulp to the diet daily during estrus synchronization and early gestation reduces the pregnancy rate, probably due to the caffeine concentration present in the by-product (Salinas-Rios et al 2016), which is a stimulant of the central nervous system (González and Ramirez-Mares, 2014). In addition to caffeine, coffee pulp contains natural antioxidants (Salinas et al 2014), which have been observed to improve the immune response (Morán et al 2012). Based on this finding, we consider that the inclusion of coffee pulp is viable at limited levels. However, there is little information on the maximum allowable limit that does not affect productivity parameters and sheep health. Current trends require products of animal origin to be safe, with a known origin ensuring that animals were provided with the necessary

\footnotetext{
Accepted: 15.03.2018.

aUniversidad Autónoma Benito Juárez de Oaxaca, Facultad de Medicina Veterinaria y Zootecnia, México.

bInstituto Tecnológico del Valle de Oaxaca, México.

*Corresponding author: salinas980@ hotmail.com
}

health conditions in the production system. However, this scenario is rarely the case because the fattening of sheep generates conditions of stress and susceptibility to disease (Galapero et al 2015). Few studies have evaluated the inclusion of different ingredients on the health statuses of sheep during fattening. Several variables measured in the blood are indicators of the health status of the animal, including cholesterol, glucose, protein, urea, creatinine, hematocrit and leukocytes (Pierre et al 2011, Kiran et al 2012, Collins et al 2016), for example, physiological state affects the blood metabolic profile (Sharma et al 2015). Coffee consumption and human health relation has been extensively studied (Lopez-Garcia et al 2013). Thus, the objective of this study was to evaluate the productivity and health of lambs fed different proportions of coffee pulp.

\section{MATERIAL AND METHODS}

The study was conducted in the municipality of La Trinidad Zaachila, Oaxaca, México located at a latitude $16^{\circ} 57^{\prime}$ North and longitude $96^{\circ} 50^{\prime}$ 'West at 1490 masl.

\section{EXPERIMENTAL DESIGN AND ANIMAL MANAGEMENT}

Thirty-five four-month-old Pelibuey crossbred male lambs with an average weight of $21.8 \mathrm{~kg}$ were used. At the beginning of the study (a week before coffee pulp suplementation), the lambs were subjected to a coproparasitoscopic examination. Based on the results, the lambs were dewormed orally with $10 \%$ Febendazole. Additionally, the lambs were vaccinated with Bobact 8 (Lab. Intervet) intramuscularly at doses of $2.5 \mathrm{~mL}$.

A completely randomised design with 5 treatments of 7 lambs each was used. The lambs were housed in individual wooden pens that were $1.0 \mathrm{~m}$ wide $\mathrm{x} 2.40 \mathrm{~m}$ long $\mathrm{x} 1.20 \mathrm{~m}$ high with an earthen floor. The treatments were 
as follows: T0: control; T1: feed with $7 \%$ coffee pulp; T2: feed with $14 \%$ coffee pulp, T3: feed with $21 \%$ coffee pulp; and T4: feed with $28 \%$ coffee pulp. Due to live weight change and nutrient requirements, two diets were used. During fattening, a starter diet was given for 56 days; fourteen days were used for adaptation, and a finishing diet was provided for 42 days. The diets were isoproteic and isoenergetic and contained $89 \%$ of dry matter, $17.0 \%$ crude protein (CP), 2.7 Mcal of ME/kg of dry matter (DM) and $9.8 \%$ of crude fiber $(\mathrm{CF})$ for the initiation stage and $89 \%$ of dry matter, $16.2 \% \mathrm{CP}, 2.7 \mathrm{Mcal}$ of ME/kg of DM and $9.8 \% \mathrm{CF}$ for the finishing stage. The ingredients were corn, soybean meal, alfalfa stubble, molasses, urea and mineral salt. The coffee pulp was dehydrated in the sun for three days, this one had $9 \%$ of CP, $30 \%$ of CF and 90 $\%$ of DM. Free access was provided to the feed and water.

DM, ash and CP were determined using the AOAC technique (1990). Neutral detergent fiber (NDF), acid detergent fiber (ADF) and lignin were determined using the Van Soest et al (1991) technique.

\section{MEASURED VARIABLES}

To measure productivity, the lambs were weighed at the beginning and end of each stage. Feed and water were provided twice a day (7:00 and 16:00 h). Feed rejection was measured weekly. Feed intake was estimated using the dry matter percentage of $89 \%$. Feed conversion ratio was calculated as feed intake divided by weight gain during fattening. At the beginning of coffee pulp supplementation and at the end of the study, $5 \mathrm{~mL}$ of jugular vein blood was collected in vacutainer EDTA tubes without anticoagulant (Becton Dickinson Vacutainer Systems, Franklin Lakes, NJ, USA). Then $3 \mathrm{~mL}$ were used for the determination of the biochemical profile, and $2 \mathrm{~mL}$ were used for the hemogram.

The cholesterol, glucose, protein, urea and creatinine concentrations were determined for the biochemical profile. For this purpose, the automated biochemical analyser ES-218 (Kontrol LAB) and the associated reagents, calibrator and DCL control were used. Endpoint and kinetic determinations were performed.

The haematocrit concentration and the leukocyte, neutrophil, monocyte, lymphocyte and eosinophil counts were determined by the hemogram. A Mex-Lab hematological analyser was used in capillary mode to determine the erythrocytic and leukocyte values. Due to the haematological characteristics of ruminants, the haematocrit was determined manually according to the microhaematocrit technique. A blood smear was prepared for the differential leukocyte count (Carr and Rodak 2009), stained with Wright's solution (MARK) for $5 \mathrm{~min}$ and then incubated with pH 7 buffer solution for 10 minutes.

At the end of the experiment, when the lambs were slaughtered, a parasite analysis was carried out.

\section{STATISTICAL ANALYSIS}

For weight gain, feed intake and feed conversion, analysis of variance was performed using the inclusion level of coffee pulp as the fixed effect and the initial live weight as the covariate. For the biochemical profile and haemogram, the initial value of each analyte was used as the covariate. The difference between means was determined by Tukey's test, with a significance value less than or equal to 0.05 .

\section{RESULTS AND DISCUSSION}

All variables had a covariant effect, which is why we present adjusted means. Different alternatives have been attempted to take advantage of the large number of by-products generated in the different phases of coffee processing. Because there is a tendency to take advantage of agricultural and industrial by-products to lower production costs (Bampidis and Robinson 2006), coffee by-products have been used in animal feed (Barcelos et al 1997) and as a source of antioxidants during sheep fattening (Salinas et al 2015). In the present experiment, feed intake (1143.51 g $\left.\mathrm{d}^{-1}\right)$, daily weight gain $\left(167.85 \mathrm{~g} \mathrm{~d}^{-1}\right)$ and feed conversion (7.02) were not modified $(P>0.05)$ by the inclusion of $28 \%$ coffee pulp (table 1 ).

Coffee pulp contains compounds such as caffeine and tannins that limit its intake (Ulloa et al 2003). Therefore, different treatments have been used to reduce these compounds and to increase the nutritional value of the coffee pulp. Treatments include the use of bacteria (Orozco et al 2008), silage and aerobic decomposition (Ulloa et al 2003). However, these processes could increase the cost. Therefore, the easiest method to provide coffee pulp to sheep is through dehydration and testing of different levels to determine the maximum inclusion where the productive parameters of the sheep are not reduced, and their health is not compromised. Despite these compounds being reported as antinutritional and the bitterness of the coffee pulp, the feed intake, weight gain and feed conversion were not differing among treatments. Previously, up to $16 \%$ coffee pulp was added to the sheep diet without affecting production parameters (Salinas et al 2015). In $201 \mathrm{~kg}$ heifers, a decrease in weight gain was reported when the inclusion of the coffee husk was $10.5 \%$ (Souza et al 2006). Likewise, a decrease in digestibility with the inclusion of coffee husks was reported.

In all treatments, the inclusion of coffee pulp in the diet of the sheep did not modify $(P>0.05)$ the cholesterol, glucose, protein, urea and creatinine concentrations in the blood (table 2). However, the urea concentration was above the reference values reported by Núñez and Bouda (2008) for healthy sheep. Multiple metabolic factors are involved in the synthesis of urea. Therefore, one possible assumption is that the percentage of protein in the diets was above the sheep's requirements because cows given a 
Table 1. Means ( \pm standard error) of feed intake, weight gain and feed conversion of lambs fed different levels of inclusion of coffee pulp in the diet.

\begin{tabular}{lccccc}
\hline & \multicolumn{5}{c}{ Treatment } \\
\cline { 2 - 6 } & $\mathrm{T} 0$ & $\mathrm{~T} 1$ & $\mathrm{~T} 2$ & $\mathrm{~T} 3$ & $\mathrm{~T}$ \\
\hline Feed intake $\mathrm{g} \mathrm{d}^{-1}$ & $1098.06 \pm 65.8$ & $1072.83 \pm 65.8$ & $1191.70 \pm 65.8$ & $1186.46 \pm 65.8$ & $1168.53 \pm 65.8$ \\
Weight gain $\mathrm{g} \mathrm{d}^{-1}$ & $161.62 \pm 13$ & $160.13 \pm 13$ & $164.67 \pm 13$ & $177.22 \pm 13$ & $175.61 \pm 13$ \\
Feed conversion & $7.04 \pm 0.23$ & $6.72 \pm 0.23$ & $7.45 \pm 0.23$ & $6.73 \pm 0.23$ & $7.18 \pm 0.23$ \\
\hline
\end{tabular}

T0: control; T1: feed with $7 \%$ coffee pulp; T2: feed with $14 \%$ coffee pulp; T3: feed with $21 \%$ coffee pulp; T4: feed with $28 \%$ coffee pulp.

Table 2. Means ( \pm standard error) of the variables related to the biochemical profiles of lambs fed different levels of inclusion of coffee pulp in the diet.

\begin{tabular}{lcccccc}
\hline \multicolumn{7}{c}{ Treatment } \\
\hline Cholesterol & T0 & T1 & T2 & T3 & T4 & Reference values \\
Glucose & $2.24 \pm 0.09$ & $2.32 \pm 0.09$ & $2.25 \pm 0.09$ & $2.34 \pm 0.09$ & $2.37 \pm 0.11$ & $0.8-2.4 \mathrm{mmol} / \mathrm{L}$ \\
Protein & $4.16 \pm 0.26$ & $4.22 \pm 0.26$ & $3.65 \pm 0.26$ & $3.66 \pm 0.26$ & $4.37 \pm 0.28$ & $3.2-4.5 \mathrm{mmol} / \mathrm{L}$ \\
Urea & $68.27 \pm 0.93$ & $68.66 \pm 0.93$ & $69.05 \pm 0.93$ & $68.88 \pm 0.93$ & $69.96 \pm 1.0$ & $60-75 \mathrm{~g} / \mathrm{L}$ \\
Creatinine & $8.37 \pm 0.31$ & $7.59 \pm 0.31$ & $8.29 \pm 0.31$ & $8.30 \pm 0.31$ & $8.53 \pm 0.33$ & $4.0-7.0 \mathrm{mmol} / \mathrm{L}$ \\
\hline
\end{tabular}

T0: control; T1: feed with 7\% coffee pulp; T2: feed with $14 \%$ coffee pulp; T3: feed with $21 \%$ coffee pulp; T4: feed with $28 \%$ coffee pulp. Reference values according to Núnez and Bouda 2008.

diet with a high protein have a higher urea concentration (Amanlou et al 2017).

Creatinine is one of the biochemical parameters used to measure muscle activity or kidney disorders. In the present study, we found that during administration of diets with or without coffee pulp, the creatinine levels were below the reference values reported by different authors (Pugh 2004, Anton and Mayayo 2007, Aceña et al 2008, Núñez and Bouda 2008). In studies with Jersey cattle, 12-month-old cattle had lower serum creatinine values than cattle older than 18 months of age (Gregory et al 2004). Therefore, the finding of creatinine values below the previously reported reference values in all treatments could be due to fattening animals having some factor that modifies this metabolite or because the reference values reported by other authors refer to animals of different ages than the crossbred animals used in the present study. Recent studies show that there is seasonal effect in the values of creatinine in sheeps decreasing in winter (Rathwa et al 2017).

The haematocrit concentration and the leukocyte, monocyte and lymphocyte counts in blood were not modified $(P>0.05)$ by the inclusion of coffee pulp. The coffee pulp significantly reduced $(P<0.05)$ the number of neutrophils in the lambs without altering the minimum reference values (table 3). Coffee pulp contains caffeine (Salinas et al 2014), which is widely used for its different physiological effects. For example, caffeine is used in children with apnea as an inhibitor of adenosine receptors and as a modulator of inflammatory processes to decrease the quantity of neutrophils by inhibiting IL-10 (Chavez et al 2011) and TNF- $\alpha$ expression (Horrigan et al 2004), and in laboratory animals as an anti-inflammatory factor for the prevention of glaucoma (Madeira et al 2016). Li et al (2011) observed that caffeine decreased the chemotaxis and phagocytic activity of neutrophils in pig spermatozoa. Additionally, caffeine has an antibiotic effect against bacteria (Ramanaviciene $e t$ al 2003, Al-Janabi 2011). Therefore, we suggest that coffee pulp decreases the number of neutrophils in lambs either through the action of caffeine on the adenosine receptors, thereby preventing the inflammatory response, or through its antibacterial activity, which indirectly decreases the amount of neutrophils in the blood.

The addition of up to $14 \%$ coffee pulp in the diet increased the number of blood eosinophils above the reference values. Eosinophils are involved in helminth immunity processes (Hogan et al 2008, Muniz et al 2012, Rosenberg et al 2013, Mkrae et al 2015). At the end of the experiment, no adult parasites or larval states were found in any treatment. The activation of eosinophils in inflammatory processes and immune response against helminths is regulated by interleukins IL-4, IL-8, IL-13 and TNF- $\alpha$ (Horrigan et al 2004, Ciepiela et al 2015). Additionally, some receptors are differentially expressed between eosinophils and neutrophils, such as the glucagon-like peptide 1 receptor (GLP-1R) (Mitchell et al 2017) and adenosine $A 3$ receptor $\left(A_{A 3} R\right)$ (Ezeamuzie 
Table 3. Means ( \pm standard error) of the hematological analysis of lambs fed different levels of inclusion of coffee pulp in the diet.

\begin{tabular}{|c|c|c|c|c|c|c|}
\hline & \multicolumn{5}{|c|}{ Treatment } & \multirow{2}{*}{ Reference values } \\
\hline & T0 & $\mathrm{T} 1$ & $\mathrm{~T} 2$ & $\mathrm{~T} 3$ & $\mathrm{~T} 4$ & \\
\hline Hematocrit & $39.47 \pm 0.50$ & $40.73 \pm 0.50$ & $39.70 \pm 0.50$ & $39.75 \pm 0.50$ & $39.04 \pm 0.55$ & $27-45 \%$ \\
\hline Leucocyte & $9.67 \pm 0.44$ & $9.00 \pm 0.44$ & $9.04 \pm 0.44$ & $8.69 \pm 0.44$ & $8.78 \pm 0.48$ & $4-12 \times 10^{9} / \mathrm{L}$ \\
\hline Neutrophil & $4.34 \pm 0.19 \mathrm{a}$ & $4.26 \pm 0.19 \mathrm{ab}$ & $4.01 \pm 0.19 \mathrm{ab}$ & $3.77 \pm 0.19 b$ & $3.70 \pm 0.21 b$ & $0.7-6 \times 10^{9} / \mathrm{L}$ \\
\hline Monocyte & $0.26 \pm 0.06$ & $0.35 \pm 0.06$ & $0.27 \pm 0.06$ & $0.36 \pm 0.06$ & $0.27 \pm 0.07$ & $0-0.7 \times 10^{9} / \mathrm{L}$ \\
\hline Lymphocyte & $3.52 \pm 0.24$ & $3.97 \pm 0.24$ & $3.58 \pm 0.24$ & $3.22 \pm 0.26$ & $3.74 \pm 0.25$ & $2-9.0 \times 10^{9} / \mathrm{L}$ \\
\hline Eosinophil & $0.95 \pm 0.18$ & $0.98 \pm 0.18$ & $1.17 \pm 0.18$ & $1.14 \pm 0.19$ & $1.21 \pm 0.20$ & $0-1.0 \times 10^{9} / \mathrm{L}$ \\
\hline
\end{tabular}

T0: control; T1: feed with $7 \%$ coffee pulp; T2: feed with $14 \%$ coffee pulp; T3: feed with $21 \%$ coffee pulp; T4: feed with $28 \%$ coffee pulp. Reference values according to Núnez and Bouda 2008.

and Philips 2003), which generates different functional and regulatory consequences). Supplementation with pulp coffee increased eosinophils count, may be pulp coffee activates innate immune response, probably through interleukin, like the findings reported by Oh et al (2017). An increase of eosinophils is being associated with an acute stress response or a gastrointestinal inflammation (Weiss and Wardrop 2010, Yantiss 2015). In the present study the lambs did not show clinical signs of any disease

Based on these results, it is concluded that the inclusion of up to $28 \%$ coffee pulp in the diet does not affect the productive parameters and does not cause significant changes in the differential leukocyte counts. However, as the pulp concentration increases, neutrophils tend to decrease without affecting the health status of the fattening lambs.

\section{REFERENCES}

Aceña C, Fernández A, Ferrer LM, Gáscon M, Gómez P, et al. 2008. Manual de prácticas de Patología General. Ed. Prensas Universitarias de Zaragoza, Zaragoza, España.

AL-Janabi AA. 2011. Potential activity of the purine compounds caffeine and aminophylline on bacteria. J Global Infect Dis 3, 133-137.

Amanlou H, Amirabadi FT, Eslamian FN. 2017. Effects of rumen undegradable protein supplementation on productive performance and indicators of protein and energy metabolism in Holstein fresh cows. J Dairy Sci 100, 3628-3640.

AOAC, Association of Official Analytical Chemists. 1990. Official Methods of Analysis. 15 ${ }^{\text {th }}$ ed. Association of Official Analytical Chemists, Washington, D. C., USA.

Bampidis VA, Robinson PH. 2006. Citrus by-products as ruminant feeds: A review. Anim Feed Sci Technol 128, 175-217.

Barcelos AF, Andrade IF, von Tiesenhausen IMEV, Ferreira JJ, Settle RS, et al. 1997. Aproveitamento da casca de café na alimentação de novilhos confinados resultados do primeiro ano. $R$ Bras Zootec 26, 1208-1214.

Carr JH, Rodak BF. 2009. Clinical hematology atlas. $3^{\text {rd }}$ ed. Saunders Elsevier, St. Louis, USA.

Chávez VR, Ahlawat R, Wills-Karp M, Nathan A, Ezell T, et al. 2011. Correlation between serum caffeine levels and changes in cytokine profile in a cohort of preterm infants. J Pediatr 158, 57-64.

Ciepiela O, Ostafin M, Demkow U. 2015. Neutrophils in asthma a review. Respir Physiol Neurobiol 209, 13-16.

Collins S, Dornburg A, Flores JM, Dombrowski DS, Lewbart GA. 2016. A comparison of blood gases biochemistry and hematology to ecomorphology in a health assessment of pinfish (Lagodon rhomboides). PeerJ 4, 22262.

Ezeamuzie CI, Philips E. 2003. Positive coupling of atypical adenosine A3 receptors of human eosinophils to adenylyl cyclase. Biochem Biophys Res Commun 300, 712-718.

Galapero J, Fernández S, Pérez CJ, García-Sánchez A, García-Sánchez L, et al. 2015. Valuation of immune response by using phagocytosis index and parameters associated as markers of animal stress in fattening lambs. Small Rumin Res 133, 58-61.

González ME, Ramírez-Mares MV. 2014. Impact of caffeine and coffee on our health. Trends Endocrinol Metab 25, 489-492.

Gregory L, Birgel EH, D'Angelino JL, Benesi FJ, Araújo WP, et al. 2004. Valores de Referência dos teores séricos da Uréia e Creatinina em bovinos da raça Jersey criados no Estado de São Paulo. Influência dos fatores etários, sexuais e da infeccção pelo vírus da Leucose dos Bovinos. Arq Inst Biol 7, 339-345.

Hogan SP, Rosenberg HF, Moqbel R, Phipps S, Foster PS, et al. 2008. Eosinophils: biological properties and role in health and disease. Clin Exp Allergy 38, 709-750.

Horrigan LA, Kelly JP, Connor TJ. 2004. Caffeine suppresses TNF-a production via activation of the cyclic AMP/protein kinase A pathway. Int Immunopharmacol 4, 1409-1417.

Kiran S, Bhutta AM, Khan BA, Durrani S, Ali M, et al. 2012. Effect of the age and gender on some blood biochemical parameters of apparently healthy small ruminants from Southern Punjab in Pakistan. Asian Pac J Trop Biomed 2, 304-306.

Li JC, Yamaguchi Y, Kondo Y, Funahashi H. 2011. Caffeine, dibutyryl cyclic-AMP and heparin affect the chemotactic and phagocytotic activities of neutrophils for boar sperm in vitro. Theriogenology $75,1336-1345$.

López-García E, Guallar-Castillón P, León-Muñoz L, Graciani A, Rodríguez-Artalejo F. 2013. Coffee consumption and health-related quality of life. Clin Nutr 33, 143-149.

Madeira MH, Ortin-Martínez A, Nadal-Nícolas F, Ambrósio AF, Vidal-Sanz M, et al. 2016. Caffeine administration prevents retinal neuroinflammation and loss of retinal ganglion cells in an animal model of glaucoma. Sci Rep 6, 1-13.

Mitchell PD, Salter BM, Oliveria JP, El-Gammal A, Tworek D, et al. 2017. Glucagon Like Peptide-1 receptor expression on human eosinophils and its regulation of eosinophil activation. Clin Exp Allergy 47, 331-338.

Mkrae KM, Stear MJ, Good B, Keane OM. 2015. The host immune response to gastrointestinal nematode infection in sheep. Parasite Immunol 37, 605-613.

Morán L, Andrés S, Bodas R, Benavides J, Prieto N, et al. 2012. Antioxidants included in the diet of fattening lambs: Effects on immune response, stress, welfare and distal gut microbiota. Anim Feed Sci Technol 173, 177-185. 
Muniz VS, Weller PF, Neves JS. 2012. Eosinophil crystalloid granules: structure, function, and beyond. J Leukoc Biol 92, 281-288.

Núñez OL, Bouda J. 2008. Patología Clínica Veterinaria. $3^{\text {a }}$ ed. Facultad de Medicina Veterinaria y Zootecnia Universidad Nacional Autónoma de México, México.

Oh J, Giallongo F, Frederick T, Pate J, Walusimbi S, et al. 2015. Effects of dietary Capsicum oleoresin on productivity and immune responses in lactating dairy cows. J Dairy Sci 98, 1-13.

Orozco AL, Pérez MI, Guevara O, Rodríguez J, Hernández M, et al. 2008. Biotechnological enhancement of coffee pulp residues by solid-state fermentation with Streptomyces. Py-GC/MS analysis. J Anal Appl Pyrolysis 81, 247-252.

Pierre PJ, Sequeira MK, Corcora CA, Blevins MW, Gee M, et al. 2011. Hematological and serum bichemical índices in healthy Bonnet macaques (Macaca radiata). J Med Primatol 40, 287-293.

Pugh DG. 2004. Clínica de ovinos e caprinos. Ed. Roca, São Paulo, Brazil.

Ramanaviciene A, Mostovojus V, Bachmotova I, Ramanavicius A. 2003. Anti-bacterial effect of caffeine on Escherichia coli and Pseudomonas fluorescens. Acta Med Litu 10, 185-188.

Ramos AJJ, Ferrer MLF. 2007. La exploración clínica del ganado ovino y su entorno. Ed. Servet, Zaragoza, España.

Rathwa SD, Vasava AA, Pathan MM, Madhira SP, Patel YG, et al. 2017. Effect of season on physiological, biochemical, hormonal, and oxidative stress parameters of indigenous sheep. Vet World 10 650-654.

Rosenberg HF, Dyer KD, Foster PS. 2013. Eosinophils: changing perspectives in health and disease. Nat Rev Immunol 13, 9-22.

Salinas RT, Sánchez TT, Ortega CME, Soto HM, Hernández BJ, et al. 2014. Changes in composition, antioxidant content, and antioxidant capacity of coffee pulp during the ensiling process. $R$ Bras Zootec 43, 492-498.

Salinas-Ríos T, Ortega-Cerrilla ME, Sánchez-Torres MT, HernándezBautista J, Díaz-Cruz A, et al. 2015. Productive performance and oxidative status of sheep fed diets supplemented with coffee pulp. Small Rumin Res 123, 17-21.

Salinas-Rios T, Sánchez-Torres MT, Díaz-Cruz A, Cordero-Mora JL, Cárdenas LM, et al. 2016. Oxidative status and fertility of ewes supplemented with coffee pulp during estrous synchronization and early pregnancy. Rev Colomn Cienc Реси 29, 255-263.

Sharma A, Kumar P, Singh M, Vasishta N. 2015. Haemato-biochemical and endocrine profiling of north western Himalayan Gaddi sheep during various physiological/reproductive phases. Open Vet J 5, 103-107.

Souza AL, García R, Salgado BF, Souza CJM, Valadares FS, et al. 2006. Casca de café em dietas para novilhas leiteiras: consumo, digestibilidade e desempenho. R Bras Zootec 35, 921-927.

Ulloa RJB, Verreth JAJ, Amato S, Huisman EA. 2003. Biological treatments affect the chemical composition of coffee pulp. Bioresour Technol 89, 267-274.

Van Soest PJ, Robertson JB, Lewis BA. 1991. Methods for dietary fiber, neutral fiber and no starch polysaccharides in relation to nutrition. J Dairy Sci 74, 3583-3597.

Weiss DJ, Wardrop KJ. 2010. Schalm's Veterinary Hematology. $6^{\text {th }}$ ed. Blackwell Publishing, Ames, IA, USA.

Yantiss RK. 2015. Eosinophils in the GI tract: How many is too many and what do they mean? Modern Patology 28, s7-s21. 
